\title{
Greenhouse Gas Emissions and Sustainability in Lagos Metropolis, Nigeria
}

\author{
Kofo A Aderogba \\ Department of Geography \& Environmental Studies, Tai Solarin University of Education \\ Ijebu-Ode, Nigeria \\ E.mail: kofoaderogba@yahoo.com
}

Accepted: November 2, 2011 Published: December 23, 2011

Doi:10.5296/ijld.v1i2.1190ＵRL: http://dx.doi.org/10.5296/ijld.v1i2.1190

\begin{abstract}
The enhancement of the greenhouse effect in driving increases in temperature and many other changes associated with climate have become great concern to research. The objective of this paper is to estimate the amount of greenhouse gases in the atmosphere in Lagos Metropolis. Literatures on road and air travels were read; and also journal articles on pollution and greenhouse gases, global warming and climate change. Newspaper cuttings, magazines, and electronic media sources of data and information were used. Trends in the growth and development of railway locomotives, marine activities, vehicular movements and air travels in the metropolis were studied and correlated with the estimated greenhouse gases emitted. There is positive correlation. Vehicular movements and air travels have increased by over 50\% in the last twenty years. Greenhouse gases are increasing by the day. There must be deliberate checks on gas emission from automobiles, plants and machineries and in the aviation industry. The world is not at rest to arrest the effects of climate change and global warming. Nigeria and Nigerians and particularly Lagosian, the government and research institutions should be parts of the efforts.
\end{abstract}

Key words: Greenhouse Gas, Emissions, Predicaments, Economic Value, Lagos Metropolis.

\section{Background to the Study:}

Generalized retreats of glaciers throughout the world, regular rise in sea level, multiplicity of heat waves and droughts, cyclones and torrential rains on the biosphere are some groups of 
symptoms of climate change, (Rojey 2009; and Dow and Dowing, 2006). In 1988, a decisive step was taken with the creation of the Intergovernmental Panel on Climate Change (IPCC), on the joint initiative of the World Meteorological Organization (WMO) and the United Nation Environmental Programme (UNEP). The third report, published in 2001, of the IPCC led to the adoption of control measures and sanctions designed to ensure effective application of the keys to Kyoto protocol (IPCC 2001). The IPCC has come up with several reports. The report, published in 2007, confirms and improves the main conclusion of the previous reports. Over 2,000 scientists from 156 countries participated in the IPCC studies that are wishing to reach a consensus of opinion on climate change phenomena and the challenges. There are more and more evidence of the correlation between an increase in Carbon Dioxide $\left(\mathrm{CO}_{2}\right)$ emission and the increase in the average temperature observed over the entire planet: Since 1860, the start of the industrial era, the average temperature on the surface of the Earth has increased by $0.8^{\circ} \mathrm{C}$, (Brian, 2004; Kershi and Simon, 2005; and Hansen, Schnitzler, Strassmann, Doney, and Roeckner, 2007). According to them, the sudden rise in average temperature since the start of the industrial era seems to be abnormal compared with past trends, both in view of its relative amplitude and the speed of the change on a geological time scale.

The activity which has increased over the past centuries, could partly explain the current warming, but certainly not the amplitude of the variation observed, nor the fact that since 1980 global warning has accelerated while solar activity has remained stable. According to the IPCC model, if the trend continues, the atmospheric Carbon Dioxide $\left(\mathrm{CO}_{2}\right)$ content could double by the end of the century, reaching a value of 750ppm, (and possibly exceeding 1,000ppm), causing disastrous climate transformation; and the average temperature increase could reach 2 $-4^{0} \mathrm{C}$ by the end of the century, possibly even $6^{0} \mathrm{C}$ (Flannery 2005; and Nicholas 2007) while an increase of more than $2^{0} \mathrm{C}$ is considered unbearable, (Rojey, 2009).

By and large, $\mathrm{CO}_{2}$ is massively emitted into the atmosphere and it behaves like a greenhouse gas. The atmosphere is transparent to the incident solar radiation transmitted in the visible light spectrum, but some of the solar energy received by the Earth is reflected back as infrared radiation. This radiation can be partly stopped by some gases present in the atmosphere, the 
green house gases, and returned to the earth whose surface warms up accordingly. Carbon dioxide is not the only greenhouse gas. Other gases, such as methane, nitrous oxide and ozone produced by human activity contribute to the thermal imbalance of the Earth. Therefore, the objective of this paper is to identify the sources and estimate the amount of the anthropogenic greenhouse gases over Lagos Metropolis. It also suggests some palliative measures for reducing its long term negative effects for physical and economic sustainable development.

\section{The Study Area - Lagos Metropolis:}

The Metropolis is located on the creek in the extreme south west of Nigeria. That is, it is boarded in the south by the Bight of Benin. The population was about 500,000 people by 1965 , but grew to 3million in 1975. Ogunbiyi (2011) assert that "Lagos is presently experiencing phenomenal population explosion; and it is being projected to be the third largest megacity in the world by 2015." Many are of the views that despite the 10 million figures declared by the National Population Commission in the last census exercise, the city's best population is 40 million. Whereas the annual population growth in the developing world is $3 \%$ and Nigeria is 2.7\%; that of Lagos stands at a stunning 8\% and "is likely to accelerate", (Ogunbiyi, 2011). The Metropolis is the commercial nerve center of Nigeria and indeed West Africa with peculiar infrastructural challenges. Its sheer human density driven by an increasing population due to endless survival and economic driven immigration, its ports and waterways, its border with Benin Republic, its high concentration of banks, industries, companies and other commercial enterprises makes it a very complex megacity with multiplicity of challenges, and to govern. Toady, "Lagos handles about 9,000 metric tones of refuse daily, more than what the whole of Ghana is generating. The branch networks that some banks have in Lagos outstrip what they have in the whole country" (Ogunbiyi, 2011). According to him, a recent study reveals that over 20,000 people from across the world move into Lagos for various reasons on a daily basis. She is the bane through which the world views Nigeria. Incidentally, it appears the successive Federal Governments have not taken cue from countries and governments that similarly relocated their national capitals: Germany, Brazil, Malaysia, Australia and Tanzania. 


\section{The Greenhouse Gas:}

Greenhouse gases often trap heat in the atmosphere (Cox, Betts, Jones, Spall, and Totterdal, 2000; Brian, 2004; Fahey, 2007; and Seetharam, and Udaya-Simba, 2009). Some of the gases such as carbon dioxide occur naturally and are emitted to the atmosphere through natural processes (mainly ice cores, water vapour, colossal volcanic out gassings, decomposition of limestone, atmosphere/ocean heat exchange, mountain building and continental drifts); and various human (anthropogenic) activities, (Raupach, 2007). Others, such as fluorinated gases are created and emitted solely through human

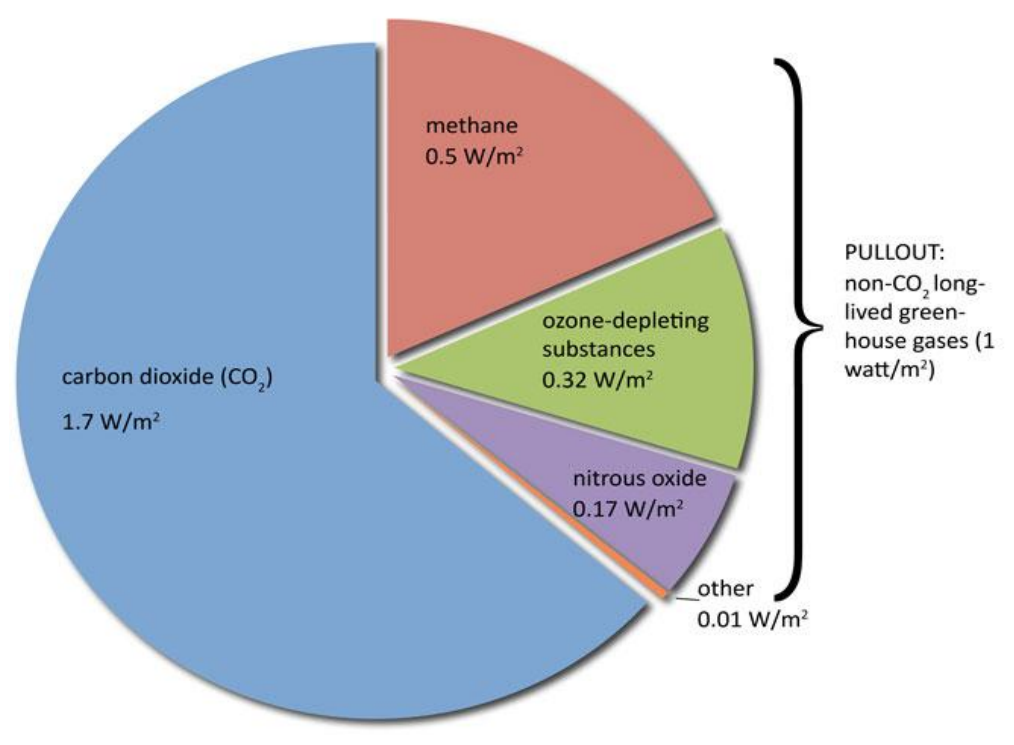

Figure 1: Average Contribution of Greenhouse Gases in the Air.

activities. Principal among them that enter the atmosphere because of human activities and their average composition is as shown in Figure 1; and they are best described as follows (IPCC, 2007):

Carbon Dioxide $\left(\mathrm{CO}_{2}\right)$ that enters the atmosphere through the burning of fossil fuels, solid wastes, trees and wood products, and as a result of other chemical reactions. It is removed from the atmosphere when it is absorbed by plants as part of the biological carbon cycle; 
Methane $\left(\mathrm{CH}_{4}\right)$ which is emitted during the production and transportation of coal, natural gas, and oil. Its emission also results from livestock, poultry and other agricultural practices and by the decay of organic waste in municipal solid waste landfills;

Nitrous Oxide $\left(\mathrm{N}_{2} \mathrm{O}\right)$ is emitted during agricultural and industrial activities, as well as during combustion of fossil fuels and solid waste; and

Fluorinated Gases which includes Hydrofluorocarbons, perfluorocarbons and sulphur hexafluoride are synthetic, powerful greenhouse gases that are emitted from a variety of industrial processes. These are sometimes used as substitutes for ozone-depleting substances. They are typically emitted in smaller quantities, but referred to as High Global Warming Potential gases ("High GWP gases") because they are potent greenhouse gases.

The Greenhouse gas inventory is an accounting of the amount of greenhouse gases emitted to or removed from the atmosphere over a period of time, say one year, (Seetharam, and Udaya-Simba, 2009). A greenhouse gas inventory also provides information on the activities that cause emissions and removals, as well as background on the methods used to make the calculations, (Brian, 2004). Scientists use greenhouse gas inventories as inputs to atmospheric and economic models, (Fahey, 2007). Policy makers use greenhouse gas inventories to track emission trends, develop strategies and policies and assess progress, (Rudrappan, 2011).

In United States of America, to track the national trend in emissions and removals since 1990, EPA develops the official US greenhouse gas inventory each year. The National greenhouse gas inventory is submitted to the United Nations in accordance with the Framework Convention on Climate Change. In addition to the US inventory, greenhouse gas emission can be tracked at the global, state and local levels as well as by companies and individuals. For instance, it is known that individual produce greenhouse gas emission through everyday activities such as driving and using air conditioning or heating. US EPA develops and provides an online calculator for estimating global, regional, local and personal emissions, (Wikipedia, 2006). 
Similarly, IPCC (2006 and 2007) published internationally accepted inventory methodologies that serve as a basis for all greenhouse gas inventories, ensuring that they are comparable and understandable. Specifically, the 2006 IPCC Guidelines provides methodology for estimating national inventories for anthropogenic emissions by sources and removals by sinks of greenhouse gases. It was prepared in response to an invitation by the Parties to the UNFCCC. It is in five volumes.

However, Blacksmith Institute (2007 ) and IPCC (2007) present and assert that the contributions of the greenhouse gases depend on their Global Warming Potentials (GWP) which measures the absorption of infrared radiation emitted back into the atmosphere, and these actually form major greenhouse gases that contribute to the thermal imbalance of the earth, viz:

\begin{tabular}{lc} 
Greenhouse Gas & Global Warming Potential (GWP) \\
Carbon Dioxide $\left(\mathrm{CO}_{2}\right)$ & \multicolumn{2}{c}{1} \\
Methane $\left(\mathrm{CH}_{4}\right)$ & 22 \\
Nitrous Oxide $\quad\left(\mathrm{N}_{2} \mathrm{O}\right)$ & 310 \\
Ozone Sulphur hexafluoride & 23,900
\end{tabular}

Generally, it is measured in metric tons of Carbon equivalent, (MTCE); or metric tons of carbon dioxide equivalent, $\left(\mathrm{MTCO}_{2} \mathrm{E}\right)$. That is: (1 short ton $x-3.72 \mathrm{MTCE} /$ short ton $)-(1$ short ton $x$ 0.01 MTC / shot ton $)=3.73 \mathrm{MTCE},($ IPCC, 2007).

\section{Data Sources and Collection:}

Literatures were extensively perused on the greenhouse gases in developed and developing countries. Similarly, relevant references were contacted on pollution and pollution control. The World's Most Polluted Places: The Top Ten of Blacksmith Institute (2007) were perused - the sites and locations; major pollutants and sources; scope of the problem and impacts on human health; and the clean up status. Newspaper cuttings, magazines and journals on climate change, Clean Development Mechanism (CDM) and the carbon credit concept, IPCC initiatives and progress, and others were extensively read; and used. 
Data and information about atmospheric composition were collected from Federal Meteorological Station, Oshodi and from the Meteorological Section of the Federal Air Port Authority, Ikeja. Readings were taken for five years of the air composition and activities of man at selected locations greatly marked by arable agricultural activities; high density residential areas; abattoir and livestock farming land use; agglomerated industrial areas; markets and stores; nodal areas, rail and water transport land use; landfills and waste disposal sites; and others across the Metropolis. Interview was conducted with the Director, Federal Airport Authority, Permanent Secretary Ministry of Environment and Physical Planning, Chairman, Road and Transport Workers Association of Nigeria, (Lagos State Branch), among others. They all provided salient facts, figures and information on pollution, emission, controls and challenges; and the way forward towards sustainable environment. Chairman, Lagos State Waste Management Board provided information and data on wastes, management, and emission challenges in particular. Lagos State Central Licensing Office provided data and information on the number of vehicles registered and probably plying the metropolis' roads. It was understood that many vehicles registered in Lagos are not plying nor used in the Metropolis but there are reasonable proportion that were registered outside the Metropolis but brought for use in the Metropolis too. No rigorous statistical analytical techniques were used but simple tables, percentages and charts. The Chemistry and Physics of emission are beyond the scope of this work. The words "Lagos", "Lagos Metropolis", and "The Metropolis“, were used interchangeably to mean Lagos Metropolitan Area that is made up of 16 Local Government Areas within Lagos State of Nigeria.

\section{Results:}

The Metropolis has come a long way: There is high concentration of urban activities and programmes that result in accumulation of wastes and generation of air, water and land pollution. There have been massive introduction of contaminants into the natural environment and causing instability, disorder, harm or discomfort to the system - physical systems and or living organisms. Air pollution and pollutants include but not limited to particulates, sulphur dioxide, and heavy metals (nickel, copper, cobalt, lead, selenium, phenols, and hydrogen sulphide) and 
Table I: Selected Land Use, Locations and Estimated Total Global Warming Potential

\begin{tabular}{|l|l|c|}
\hline \multicolumn{1}{|c|}{ Land Use } & \multicolumn{1}{c|}{ Location } & Estimated GWP \\
\hline Landfill and Dumps & Oke-Odo, Yaba, Ajegunle, Oke-Afa & 101 \\
\hline High Residential Area & Mushin, Oko Baba, Ajegunle & 44 \\
\hline Hospitals and Schools & Idiaraba, Yaba, & 32 \\
\hline Low Residential Area & Victoria Island, Ikeja (GRA) & 21 \\
\hline Agricultural Activities & Ipaja, Ajah, Agege & 56 \\
\hline Transport Land Use & Ido, Mushin, Mile 2 & 68 \\
\hline Livestock and Poultry & Apapa, Mushin, Abattoir (Agege) & 98 \\
\hline Industrial Estate (Land Use) & Ikeja, Apapa, Isolo & 103 \\
\hline Markets and Stores & Balogun, Oshodi, Mushin & 95 \\
\hline Marine Activities & Marina, Wharf, Badia & 96 \\
\hline
\end{tabular}

others. The estimated Total Global Warming Potential is highest at Industrial Estates of Ikeja, Apapa and Isolo (103), landfills and dumps of Oke-Odo, Yaba, Ajegunle and Oke-Afa (101), Marine land use of Marina, Wharf, and Badia (96), Market and Store of Balogun, Oshodi, Mushin and Mile 12 (95), and livestock and poultry of Apapa, Mushin, and Agege Abattoir (98). It is lowest at the Low Residential Areas of Victoria Island and Ikeja Government Reservation Areas (GRA), 21. See Table I. There is nowhere it is less than this (21) within the Metropolis.

Also, it is estimated that the emitted Greenhouse Gas is concentrated is the Metropolis and the immediate environment; and sector contributions to the atmosphere is as showed in Table II. Apart from the solar radiation (34\%), the highest comes from the Industrial Gases and Pollutions (22\%). Also apart from 'Other' sources (06\%), Cattle and cattle rearing areas (09\%) have the lowest. There is no locality or land use within the Metropolis that contribute less than $6 \%$.

Table II: Estimated Emission of Greenhouse Gas, by Sources, to Thermal Imbalance

\begin{tabular}{|c|r|r|}
\hline $\begin{array}{c}\text { Sources of } \\
\text { Greenhouse Gases }\end{array}$ & $\begin{array}{c}\text { Estimated Size } \\
\text { of Sources (\%) }\end{array}$ & $\begin{array}{r}\text { Estimated Contributions to } \\
\text { Thermal Imbalance (\%) }\end{array}$ \\
\hline
\end{tabular}




\begin{tabular}{|l|c|c|}
\hline Solar Radiation & 100.00 & 34 \\
\hline All Agricultural Activities & 36.86 & 10 \\
\hline Use of Fossil Energies & 87.55 & 19 \\
\hline Cattle and Paddy Fields & 31.45 & 09 \\
\hline Industrial gases and Pollution & 92.65 & 22 \\
\hline Others & 58.00 & 06 \\
\hline Total & N/A & $\mathbf{1 0 0}$ \\
\hline
\end{tabular}

Table III shows the average Greenhouse Gas Emission by transport modes per Kilometer. Contributions from Pedestrians and bicycles per Kilometer are negligible. The greatest contributions come from Heavy Duty Multiple Engine Trawlers (1127/km), Heavy Duty Multiple Engine Air Crafts (506/km) and Heavy Duty Trucks (757/km). Common Motor Cycles $(36 / \mathrm{km})$ and Tricycles $(59 / \mathrm{km})$ do contribute to Greenhouse Gas Emission too. See Table III. But there are more vehicles on the roads, which means, more emission than there are from other forms of transport modes. Therefore, on the whole, Diesel Buses, Light Trucks and Heavy Duty Trucks are the major sources of emissions from transportation modes. Also, there is positive correlation between the volume of vehicles and the emission experienced in the Metropolis. As the number of vehicles is increasing so also the amounts of Greenhouse Gases in the air do increase too. The number of vehicles was 1.33 million in the year 1992 but increased to 1.83 million, 20 years after, 2010 that is, by about $59.35 \%$ and the emission increased by $60.24 \%$. See Figure 2 . 
Table III: Average Greenhouse Gas By Transport Mode Per Kilometer

\begin{tabular}{|c|c|}
\hline Mode of Transport & $\begin{array}{l}\text { Green House Gas Emission/Vehicle/Km } \\
\text { (in metric ton carbon equivalent [MTCE]) }\end{array}$ \\
\hline Pedestrian & Negligible \\
\hline Bicycle & Negligible \\
\hline Motor Cycle & 36 \\
\hline Tricycle & 59 \\
\hline Gasoline Car & 82 \\
\hline Diesel Car & 146 \\
\hline Gasoline Mini Bus & 235 \\
\hline Diesel Mini Bus & 328 \\
\hline Gasoline Bus & 405 \\
\hline Diesel Bus & 480 \\
\hline Light Truck & 344 \\
\hline Heavy Duty Truck & 757 \\
\hline Average Engine Boat & 383 \\
\hline Train/Railway Locomotives & 396 \\
\hline Average Engine Vessel & 430 \\
\hline Heavy Duty Multiple Engine Trawler & 1127 \\
\hline Light Double Engine Aircraft & 438 \\
\hline Heavy Duty Multiple Engine Air Craft & 506 \\
\hline
\end{tabular}

Apart from emission from transportation sources, major source of power supply is standby generators that are of at least one unit per household and or business unit on the average, that is, regardless of capacity and serviceability. There is considerable emission from this source. 


\section{Discussion:}

Within two decades, between 1992 and 2010, the number of vehicles on the roads doubled and so also the amount of emission from this source. It is not unlike therefore that, at this rate, both may be more than double in the next two decades. Aside the aforementioned sources of

Figure 2: Correlation between Number of Vehicles on the Roads and Estimated Emission (1991-2010)

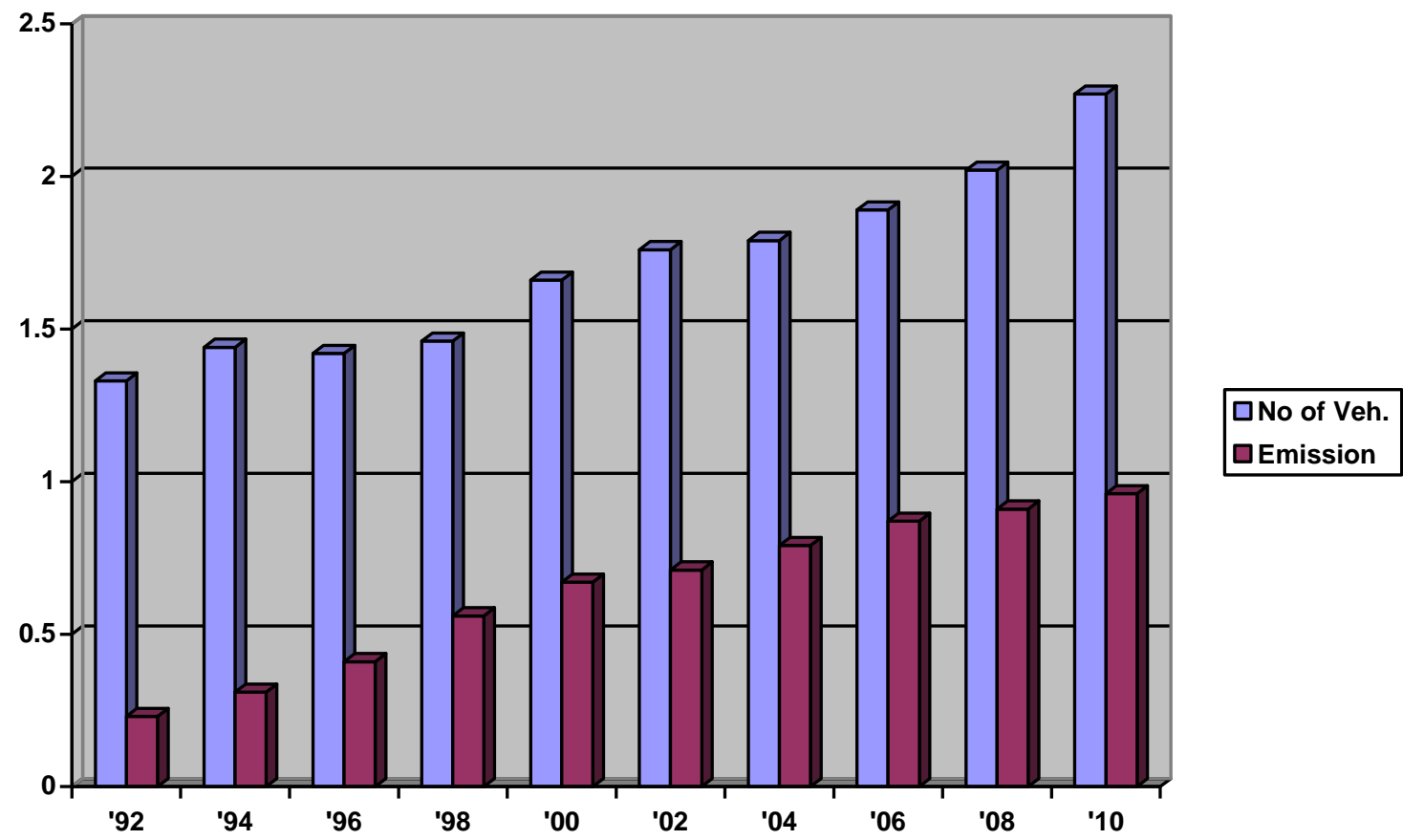

emission, electricity generating set which is a major source of power in and around the metropolis, in various capacities and shapes, are massively contributing to the emission. There are variations in the amount on hourly and daily basis: the concentration is highest during the day hours. It reaches the pick in the afternoon between 2:00 pm and 3:00 pm but starts decreasing to the lowest between the hours of 2:00 am and 6:30 am when it starts to rise again. Generally, emission is lowest during weekends; but there is no significant variation between the months of the year. Again, regardless of the sources, it is an estimated that $339,754 \mathrm{tCO}_{2}$ is generated annually.

However, introduction of contaminants into the natural environment has been causing instability, disorder, harm or discomfort to the ecosystem - physical systems and living organisms including man. These increases are in geometrical proportions and by the day. 
These have led to emission of Greenhouse Gases in various proportions into the atmosphere. Incidentally, as the urban activities kept on growing so also do the anthropogenic sources of emissions and the direct and indirect effects. Substantial parts of these are not immediately noticed by both the producers and the affected, (Blacksmith Institute, 2007). Long run effects could be very devastating; and it may not be too long before the present precarious condition will double in the metropolis and the immediate environ if appropriate checks are not put in place.

Being the bane through which the world views Nigeria, granting a special status to Lagos Metropolis and the state at large remains the best possible ways to drive Nigeria's development with needs that align with its growth. It is now time for Nigeria to imitate Germany, Brazil, Malaysia, Australia and Tanzania, which after relocating their capitals, did not hold back developmental programmes targeted at the formal capitals. The need to accord a special status for the Metropolis should not be dragged into political imbroglio. Any investment in Lagos State and in the Metropolis in particular will be a necessary blueprint for the development of the nation.

Both State and Local Governments of the Metropolis should venture into the establishment of Carbon Project. It is relatively cheap to establish and run the business. Establishment of carbon project will boost any Community Based Developmental Programmes and increase the state's Internally Generated Revenue (IGR): If an estimated 339,754t $\mathrm{CO}_{2}$ could be generated per annum, it will translate to 5,096,310 USD, that is, at $15 \mathrm{USD} / \mathrm{tCO}$. Asides, it will ultimately help reduce Greenhouse Gases in the atmosphere such as trapping and sequestering Carbon Dioxide $\left(\mathrm{CO}_{2}\right)$.

\section{Recommendation and Conclusion:}

The environmental impacts of the urban activities requires that the three tiers of government, organizations, philanthropies and individuals (and international organizations including Non-governmental Organizations) focus more attention on the causes, sources, effects and reduction of GHGs in the urbanized cnters, not only of Nigeria but anywhere on the globe. All 
hands must be on deck to reduce the industrial and municipality pollution into the environment because it subsequently leads to gas emission.

There must be slow growth in the population of the Lagos Metropolis to be able to reduce anthropogenic activities. Emphasis must be on healing degraded or destroyed natural vegetation and general landscape so that the former can serve as powerful net removers of the atmospheric carbon and greenhouse gases. Institutional mechanism such as Innovation Center should be established for adoption of technologies and products for climate mitigation and adaptation purposes. Climate mitigation and adaptation strategy should be reframed as an agenda of hope, growth, innovation, opportunity and an instrument for poverty reduction. The Government of the metropolis must take advantage of the Clean Development Mechanism $(\mathrm{CDM})$ and the carbon credit concept as the United Nations is encouraging the developing countries. There must be deliberate checks on gas emission from automobiles, plants and machineries and in the aviation industry. The world is not at rest to arrest the effects of climate change and global warming. Nigeria and Nigerians and particularly Lagosian, the government and research institutions should be parts of the efforts.

Lagos Metropolis is not an island. Nigeria and of course, Africa must have a change of directions and a holistic rethink. Particularly for the entire nation, in order to reconcile climate change and economic growth, Nigeria needs to have good governance and strong institution along with economic and political stability. Community participation is desirable for effective implementation of adaptation and mitigation strategies. Members of communities may have to be trained for skill development to manage weather vulnerabilities as climate risk managers of each local community.

The time is now; all countries have to redouble their efforts to scale up climate change mitigation and adaptation initiatives that will enable them embark upon a carbon neutral high growth for a socially equitable climate resilient sustainable development. The Metropolis, Nigeria and of course, African should not be left in the wood. 


\section{References:}

Aderogba, K. 2011. "Global Warming, Climate Change, Inclement Warmth, Acid Rain and Sustainable Development in Lagos Metropolitan Area, Nigeria." Paper Presented at the $52^{\text {nd }}$ Annual Conference of Association of Nigeria Geographers held in Othman Dan Fodio University, Sokoto, Nigeria, (March).

Akanni, C. O. 2010. Spatial and seasonal analyses of traffic-related pollutant concentration in Lagos Metropolis, Nigeria. African Journal of Agricultural Research. Vol. 5 No. 11, pp $1264-1272$.

American Environmental Protection Agency. 2007. "Solid Waste Management and Greenhouse Gases: A Life-Cycle Assessement of Emissions and Skin". (EPA530-R-03-006), available for free document on the Report, papers, and presentations section of the site.

Ayoade, J. O. 2003. Climate Change: A Synopsis of its Nature, Causes, Effects and Management. Ibadan: Vantage Publishers.

Basawaraja, R., Chari, K. B., Mise, S. R. and Chetti, S. B. 2011. "Analysis of impact of urban sprawl in altering the land-use, land-cover pattern of Raichur City, India, using geographical technologies”. Journal of Geography and Regional Planning. Vol. 4 No. 8, pp455 - 462.

Blacksmith Institute, 2007. The World's Most Polluted Places: The Top Ten. New York: Blacksmith Institute, pp. $27-31$.

Brian, D. 2004. Climate change, ozone depletion and the impact of ultraviolet exposure on human skin. Physics in Medicine and Biology 49 RI-RII.

Cowling, E. B. 1982. Acid precipitation in historical perspective. Environmental Science and Technology. Vol. 16 No. 2, pp 110A - 121A.

Cox, P. M, Betts, R. A, Jones, C. D., Spall, S.A. and Totterdal, I. J. 2000. Acceleration of global warming due to carbon-cycle feedbacks in a coupled climate model. Nature. No. 408.

Dania A. 2011. “Climate Change Worse Than Terrorism”. Vanguard: Towards Better Life for the People. Vanguard Media Limited. Vol. 25. No. 61435 p. 34.

Dow, K. and Downing, T. E. 2007. The Atlas of Climate Change: Mapping the World's Greatest Challenge. Brighton: Earthscan, pp. 19-26.

Fahey, D. W. 2007. Twenty Questions and Answers About The Ozone Layer: 2006 Update. Communiqué of the update of the 77 scientists who attended the panel review meeting for the 2006 ozone assessment (Les Diablenets, Switzerland, 19-23 June 2006). Questions 1, 9, and 10.

Hansen, J, Schnitzler, K. G, Strassmann, K, Doney, S and Roeckner, K. G. 2007. Climate change and trace gases. Phil. Trans. Roy. Soc. A 365: 1925-1954.

Hassan, T. A. 2010. Climate change: Food prices may soar in Nigeria. In Daily Trust. Abuja: Media Trust Nigeria Ltd. (Tuesday, September 21); p. 19. 
Intergovernmental Panel on Climate Change 2000, Land Use, Land Use Change and Forestry. R. T. Watson, I. R. Noble, B. Bolin, N. H. Ravindranath, D. J. Verardo and D, J. Dokken, (Eds.) Cambridge: Cambridge University Press. 375pp.

Intergovernmental Panel on Climate Change. 2001. Climate Change 2001: Impacts, Adaptation and Vulnerability. Contribution of Working Group II to the Third Assessment Report of the IPCC. J. J. McCarthy, A. A. Ganziani, N, A. Leary, D. J. Dokken and K. S. White (Eds.) Cambridge: Cambridge University Press. 103 pp.

Intergovernmental Panel on Climate Change 2007. Climate Change 2007: Impacts, Adaptation and Vulnerability. Contribution of working group II to the Fourth Assessment Report of the intergovernmental Panel on Climate Change. Cambridge: Cambridge University Press.

Kershi, J. and Simon, R. 2005.The Essentials of the Environment. London: Hodder Arnold. pp $30-39$.

Nicholas, O. and Umehai, M. C. 2009. "Effects of Climate Change on the Livelihoods of Wetland Inhabitants in Nigeria: A Review" in R. N. C. Anyadike, I. A. Madu and C. K. Ajaero (Eds.) Climate Change and the Nigerian Environment. Nsukka: Department of Geography, University of Nigeria.

Nigeria Meteorological Agency 2010. "Thirty-five Years Climate Data of Lagos Metropolis". Mimeograph. Oshodi: NMA.

Ogunbiyi, Tayo 2011. "View Point: Giving Lagos a special status" in Vanguard: Towards a better life for the people. Lagos: Vanguard Media Limited. Vol. 25: No. 6,1425 (Friday, August 5), p. 19.

Ogundipe, O. M. 2008. Environmental Degradation and Global Warming: The Challenges for Sustainable Transportation in Nigeria". Research Journal of Applied Sciences. 5 (2) pp 133 -137.

Raupach, M. R. 2007. Global and Regional Drivers of Accelerating CO2 Emissions. Proce. Nat. Acad. Sci. Vol.104, No.24; pp 10288 - 10293.

Rojay, A. 2009. Energy and Climate: How to Achieve a Successful Energy Transition. Columbus: John Wiley \& Sons Inco.

Rudrappan, D. 2011.Reconcilling Climate Change and Economic Growth: The Need for an Alternative Paradigm of Development. $34^{\text {th }}$ Public Lecture of Covenant, University. Canaan Land, Ota, Ogun State, Nigeria.

Sanjay, R, 2011. Integrated approach to solid waste management in Pune City". Journal of Geography and Regional Planning. (August) Vol. 4, No 8, pp 449 -454.

Seinfeld, J. H and Pandis, S. N 1998. Atmospheric Chemistry and Physics - From Air Pollution to Climate Change. John Wiley and Sons, Inc.

Seetharam, A. L and Udaya-Simba, B. L. 2009. Urban air pollution by timeliness analysis. Environenergy Proceeding of international conference in energy and environment (March 19-21) pp. 51-54. 


\section{Macrothink

Shaheen, E. I. (1992): Technology of Environmental Pollution. Tulsa: PennWell Publishers Coy. (Second Edition) pp. 39-110.

United Nations, 2007. Sustainable Development Issues. Geneva: UN Division for Sustainable Development (issues).

United States National Academy of Sciences 2002. Abrupt Climate Change: Inevitable Surprises. Academy of science (June).

World Bank 2004. Reducing Air Pollution from Urban Transport. Washington DC: World Bank.

World Health Organization (2005): WHO Air Quality Guidelines Global update 2005. Geneva: WHO http://www.euro.who.int/Document/E87950pdf

Wikipedia (2006): The free Encyclopaedia. Wikipedia contributors (Disclaimer) licensed under the GNU free documentation licence. Published by Lexicon Publishing Group LLC www.wikipedia.com

Wright, L. and Fulton, L. 2005. Climate Change Mitigation and Transport in Developing Nations”. Transport Review. 25 (6) pp 394 - 717. 